\title{
REKRUTMEN KANDIDAT PEREMPUAN OLEH PARTAI POLITIK (STUDI KASUS: PILKADA KABUPATEN MUARO JAMBI TAHUN 2017)
}

\author{
Diah Anggraini \\ Jurusan Ilmu Politik Fakultas Ilmu Sosial dan Ilmu Politik Universitas Andalas \\ diah.ditara88@gmail.com
}

\begin{abstract}
Abstrak
Partai politik merupakan pilar utama demokrasi. Peran dan fungsi partai politik dalam kehidupan berdemokrasi suatu negara merupakan hal yang krusial. Salah satu fungsi partai politik yang patut menjadi sorotan adalah, proses rekrutmen politik. Pemilihan kepala daerah (pilkada) sebuah bentuk proses pencerminan prinsip demokrasi yang prosesnya melalui pemilihan oleh rakyat dengan memberikan mandat kepada orang-orang yang dipercaya untuk mengelola kehidupan politik. Dalam penelitian ini ditemukan bahwa proses rekrutmen politik yang dilakukan oleh partai PKB dan PAN di Muaro Jambi pada tahun 2017 ternyata didasarkan pada model sentralistik dimana keputusan akhir dalam menentukankan kandidat terjadi di tingkat DPP untukpartai PKB dan ditingkat DPP untukpartai PAN. Pada pilkada yang dilakukan di Kabupaten Muaro Jambi tahun 2017, figur perempuan memenangkan pilkada mengalahkan 3 pasangan calon laki-laki. Masnah Busro- Bambang Bayu Suseno menang di usung oleh PAN dan PKB, ternyata tidak lepas dari peran partai politik sebagai partai pengusung.
\end{abstract}

Kata Kunci: Partai Politik ; Rekrutmen; Kandidat Perempuan.

\begin{abstract}
Political parties are the main pillar of democracy in which role and function of political parties in the democratic life of a state is crucial. One of the functions of political parties that should be highlighted is the process of political recruitment. Local leader election(pilkada) is a form of the process of reflecting democratic principles that process is through the election by the people by giving a mandate to people who are trusted to manage political life.This research focuses on the recruitment process of political parties in Muaro Jambi in 2017. The approach used is qualitative with a case study method. Data collection techniques used were interviews and documentation. The selection of informants is done by using purposive sampling technique. While the data validity technique used is triangulation. This research was conducted based on the theory of political recruitment. In this study it was found that the process of political recruitment by political parties $P K B$ and PAN in Muaro Jambi in 2017 was based on the centralistic mode. The final decision of PKB in DPP level, meanwhile for the final decision of PAN in DPP level. Masnah Busro-Bambang Bayu Suseno won in the stretcher by the PAN and PKB parties, apparently it was not separated from the role of political parties as supporting parties.
\end{abstract}

Keywords:Political Parties ; Recruitment and Local Leader Election. 


\section{PENDAHULUAN}

Partai politik merupakan pilar utama demokrasi yang mana peran dan fungsi partai politik dalam kehidupan berdemokrasi suatu negara merupakan hal yang krusial. Dapat dikatakan partai politik merupakan suatu kelompok terorganisir yang anggota-anggotanya mempunyai orientasi, nilai-nilai dan cita-cita yang sama dengan tujuan memperoleh kekuasan politik dan merebut kedudukan politik dengan cara yang konstitusional untuk melaksanakan programnya (Budiarjo, 2010).

Secara umum partai politik memiliki empat fungsi, agar dapat menjadi wadah bagi masyarakat untuk berpartisipasi dalam pengelolaan kehidupanbernegara dan memperjuangkan kepentingan dihadapan masyarakat.Partai politik sebagai bagian dari infrastruktur politik menjalankan beberapa fungsi, salah satunya adalah rekrutmen politik.

Salah satu fungsi partai politik yang patut menjadi sorotan adalah, proses rekrutmen politik. Rekrutmen politik merupakan fungsi yang sangat penting bagi partai politik. Fungsi rekrutmen politik ini menjadi fungsi ekslusif partai politik dan tidak mungkin ditinggalkan oleh partai politik.Pengorganisasian masyarakat diluar partai politik tidak menjalankan fungsi rekrutmen politik, karenanya fungsi ini sekaligus menunjukkan pembedaan paling nyata antara partai politik dan bukan partai politik. ${ }^{1}$ Susan Scarrow dalam bukunya Political Parties Democracy menjelaskan bahwa partai politik merupakan anak dari demokrasi.Partai politik memiliki tugas untuk mengartikulasi kehendak publik, mengadakan pendidikan politik, mengambarkan dan menawarkan alternatif kebijakan dan menyediakan pilihan politik kepada masyarkat dalam pemilu.

Pembentukan partai politik dimaksudkan untuk menjadi kendaraan yang sah untuk menyeleksi kader-kader pemimpin negara pada jenjang-jenjang dan posisi-posisi tertentu. Kader-kader itu ada yang dipilih secara langsung oleh rakyat, ada pula yang dipilih melalui cara yang tidak langsung. Partai politik harus menjalankan fungsinya dengan baik, terutama fungsi rekrutmen politik agar tercipta kader-kader yang berkualitas.Gabriel Almond menjelaskan bahwa proses rekrutmen merupakan kesempatan rakyat untuk menyeleksi kegiatan-kegiatan politik dan jabatan pemerintahan melalui penampilan dalam media komunikasi, menjadi anggota organisasi, mencalonkan diri untuk jabatan tertentu, pendidikan dan latihan ${ }^{2}$. Tujuan dari dilakukanya rekrutmen politik untuk sirkulasi jabatan politik dengan melibatkan partisipasi yang dilakukan oleh masyarakat secara aktif.

Undang-Undang Nomor 2 Tahun 2011 Tentang Partai Politik, pasal 29 ayat 1 telah menjelaskan bahwa

\footnotetext{
${ }^{1}$ Sigit Pamungkas, Partai Politik: Teori dan Praktik di Indonesia, Institute for Democracy and Welfarism, Yogyakarta, $2011 \mathrm{hlm} .89$

${ }^{2}$ Muhadam Labolo \& Teguh Ilham, Partai Politik dan Sistem Pemilihan Umum di Indonesia, Jakarta: Rajawali Press, 2015, hal. 17.
} 
"Partai Politik melakukan rekrutmen terhadap warga negara Indonesia untuk menjadi:

a. Anggota Partai Politik;

b. Bakal calon anggota Dewan Perwakilan Rakyat dan Dewan Perwakilan Rakyat Daerah;

c. Bakal calon kepala daerah dan wakil kepala daerah; dan

d. Bakal calon Presiden dan Wakil Presiden." ${ }^{3}$

Dalam Undang-Undang Nomor 2 Tahun 2011 Tentang Partai Politik pasal 29 ayat 2 menyebutkan bahwa

"Proses rekrutmen partai politik harus dilakukan secara demokratis dan terbuka sesuai dengan AD/ART serta perundangundangan yang berlaku"4

Rekrutmen politik secara demokratis mempunyai makna yaitu berlandaskan pada nilai-nilai dan prinsip demokrasi yaitu kebebasan, kesamaan atau keadilan dan kedaulatan suara mayoritas. Sedangkan makna keterbukaan diartikan sebagai upaya partai politik untuk menerima semua golongan atau kelompok masyarakat untuk bergabung dengan partainya dan mengikuti pembinaan serta proses kaderisasi diinternal partai.

Demokrasi yang ditandai dengan adanya komponen partai politik dan pemilihan umum yang di selenggarakan secara berkala, di Indonesia menentukan kepala daerah melalui pemilu yang demokratis telah di laksanakan sejak tahun 2005 sampai dengan sekarang. Pemilihan kepala daerah (pilkada) sebuah bentuk proses pencerminan prinsip demokrasi yang prosesnya melalui pemilihan oleh rakyat dengan memberikan mandat kepada orang-orang yang dipercaya untuk mengelola kehidupan politik. Panggung pilkada yang biasanya hanya diisi oleh kebanyakan laki-laki, kini telah bertambah ke aktor baru, perempuan, yang kini turut meramaikan euforia pilkada. Pilkada sebagai alat demokrasi yang secara substantif tidak dapat mengabaikan keterlibatan perempuan.

Fenomena ini menunjukkan bahwa kuatnya demokratisasi di daerah.Sebelumnya marginaliasi perempuan dalam ruang politik merupakan fenomena yang nyata.Marginalisasi perempuan telah menghambat ruang gerak politik bagi perempuandi Indonesia.Penyebab dari kurangnya partisipasi perempuan yang duduk di kursi kepala daerah tidak terlepas dari persoalan cultural, yaitu telah berkembangnya secara meluas budaya patriarki.Perempuan di pandang sebelah mata ketika mencoba masuk dalam dunia politik. Terlebih lagi, dari prespektif agama yang di yakini masyarakat umum di Indonesia yang mana sosok perempuan tidak lazim untuk duduk sebagai pemimpin.

\footnotetext{
${ }^{3}$ Undang-undang No 2 Tahun 2011, tentang Partai Politik

${ }^{4}$ Ibid
} 
Sulitnya figur perempuan terpilih dalam kursi eksekutif tidak terlepas dari peranan partai politik.Partai politik seharusnya menjembatani perempuan agar dapat maju dalam pilkada. Sering kali dalam proses mencari kandidat untuk maju dalam pilkada, partai poitik lebih cenderung untuk melihat elektabilitas dan modal yang dimiliki oleh calon kandidat. Figur perempuan jarang memenuhi faktor elektabilitas.Lebih jauh partai politik tidak memiliki kader perempuan yang memadai untuk maju dalam pertarungan kursi kepala daerah.

Pemilihan kepala daerah tahun 2017 diikuti oleh 44 orang perempuan dari 614 bakal calon kepala daerah yang terdaftar. Bakal calon kepala daerah perempuan tersebut tersebar di 41 wilayah pemilihan yang terdiri dari 28 di tingkat kabupaten 9 di tingkat kota dan 4 di tingkat provinsi. ${ }^{5}$ Persentase bakal calon kepala daerah perempuan menurun di bandingkan dengan pilkada tahun 2017.Persentase bakal calon perempuan pada tahun 2015 sebanyak $7,45 \%$ terjadi penurunan $0,30 \%$ pada pilkada 2017 , menjadi $7,17 \%$. Dari 44 orang perempuan bakal calon kepala daerah 38 orang maju di usung oleh partai politik, sedangkan 5 orang maju melalui jalur independent. Terdapat 23 orang bakal calon kepaladaerah perempuan dan 21 orang bakal calon wakil kepala daerah. ${ }^{6}$ Di jabarkan melalui tabel berikut:

Tabel 1.1 Bakal Calon Kepala Daerah Perempuan di Pilkada 2017

\begin{tabular}{ccc}
\hline No. & $\begin{array}{c}\text { Bakal Calon Kepala } \\
\text { Daerah }\end{array}$ & Jumlah \\
\hline 1. & Bakal Calon Gubernur & 2 Orang \\
2. & Bakal Calon Wakil & 2 Orang \\
& Gubernur \\
3. & Bakal Calon Walikota & 6 orang \\
4. & Bakal Calon Wakil & 4 Orang \\
& Walikota & 15 Orang \\
5. & Bakal Calon Bupati & 15 Orang \\
6. & Bupati & 44 Orang \\
\hline
\end{tabular}

Pilkada yang dilakukan di Kabupaten Muaro Jambi tahun 2017, figur perempuan memenangkan pilkada mengalahkan 3 pasangan calon laki-laki.Masnah Busro-Bambang Bayu Suseno menang di usung oleh partai PAN dan PKB. Dari hasil survei elektabilitas sebelumnya dimenangkan oleh kandidat lain, yakni Ivan Wirata. Berikut ditampilkan hasil

\footnotetext{
${ }^{5}$ Maharddhika, Perempuan Calon Kepala Daerah di Pilkada 2017, Jakarta: Perludem, 2017, hal 3.

${ }^{6} \mathrm{Ibid}: \mathrm{hlm} .17$
} 
survei yang dilakukan oleh Lembaga Charta Politika sebagaimana tampak dalam tabel berikut ini:

\section{Tabel 1.2 Hasil Survey Elektabilitas Calon Bupati Muaro Jambi}

\begin{tabular}{ccc}
\hline No. & $\begin{array}{c}\text { Nama Calon } \\
\text { Bupati }\end{array}$ & $\begin{array}{c}\text { Elektabilitas } \\
(\%)\end{array}$ \\
\hline 1. & Ivan Wiranta & $42,8 \%$ \\
2. & Agustian Mahir & $19,8 \%$ \\
3. & Dodi Sularso & $4,5 \%$ \\
4. & Masnah Busro & $4,3 \%$ \\
5. & Bambang Bayu S & $4,0 \%$ \\
6. & Ahmad Haikal & $3 \%$ \\
7. & Kamaludin Hafis & $3 \%$ \\
8. & Kemas Fuad & $1,8 \%$ \\
9. & Abun Yani & $1,5 \%$ \\
10 & Zulkifli & $1,3 \%$
\end{tabular}

Sumber: Survei Charta politika di muat diMetrojambi.com

Berdasarkan data dari tabel di atas, elektabilitas tertinggi di peroleh Ivan Wiranta sebesar 42,8\%. Sedangkan Masnah Busro hanya memperoleh 4,3\%. PAN dan PKB tetap mengusung pasangan Masnah Busro dan Bambang Bayu Suseno walaupun elektabilitas keduanya tidak melampaui Ivan Wiranta.

Figur Masnah Busro bukan wajah baru di panggung politik Muaro Jambi. Awal karir politik Masnah Busro diawali melalui PAN. Mengawali karir politik menjadi kader PAN. Mulai dari tahun 2005-2007 dipercaya menjabat sebagai bendahara PAN kecamatan Kumpeh Ilir.Pada tahun 2007 terpilih menjadi ketua PAN Kecamatan Kumpeh Ilir.Sejak tahun 2015, Masnah Busro pindah dan menjadi Wakil ketua Golkar Provinsi Jambi.

Masnah Busro mengawali pertarungan politik pada pileg tahun 2009 untuk dapil Kabupaten Muaro Jambi melalui PAN, namun tidak terpilih, hanya mengantongi perolehan 1.187 suara. Pada tahun 2011 sempat mencalonkan diri sebagai Bupati Muaro Jambi berpasangan dengan Arifin, menempati posisi kedua dengan persentase perolehan suara 24,13\%. Sementara bupati terpilih Burrhanuddin Mahir mendapatkan persentase perolehan 
suara sebesar 47,44\%. Masnah Busro kembali mengikuti pileg 2014 untuk Provinsi Jambi melalui partai Golkar, terpilih dengan perolehan 13.351 suara. $^{7}$

Fenomena perempuan dalam politik merupakan isu yang hangat untuk ditelaah lebih dalam, terutama ketika dikerucutkan pada isu potensi duduknya perempuan di jabatan politik. Keterpilihan perempuan untuk duduk di jabatan politik merupakan isu yang banyak diperdebatkan di banyak media mainstream. Keterpilihan perempuan untuk duduk di kursi politik bukan fenomena yang lumrah pada awalnya ada marjinalisasi perempuan dalam dunia politik yang membuat perempuan sulit melakukan penetrasi dalam partisipasi politik aktif.

Fenomena kemunculan perempuan dalam dunia politik memiliki sejarah yang panjang. Perempuan dan politik mungkin bukan kombinasi yang cocok di mata public. Ketika menarik sejarah kebelakang, fenomena ini di dorong oleh kesadaran perempuan di perlakukan tidak adil dalam setiap aspek social. Kesadaran adanya kesenjangan yang terjadi terhadap perempuan, melatarbelakangi disahkan Undang- Undang Nomor 7 tahun 1984 tentang Pengesahan Konvensi PBB Mengenai Penghapusan Segala Bentuk Deskriminasi Terhadap Wanita. Kemudian terbitnya Instrusi Presiden Nomor 9 Tahun 2000 tentang Pengarusutamaan Gender dalam Pembangunan Nasional dengan harapan agar marginalisasi perempuan dalam berbangsa dan bernegara dapat terhapuskan.

Diperlukan usaha lebih untuk menembus batasan perempuan dalam berpolitik, melalui Inpres nomor 9 tahun 2000 diharapkan perempuan dapat ikut turut dalam proses pembuatan kebijakan. Undang-Undang nomor 2 tahun 2011 tentang Partai politik menjadi gebrakan besar bagi selurus proses politik di Indonesia. Perubahan yang mendasar yakni diharuskan kepengurusan perempuan dalam partai harus 30\% baik pada tingkat provinsi ataupun kabupaten/kota. Perubahan ini tertuang dalam pasal 29 ayat 1(a) sebagai berikut:

"Rekrutmen sebagaimana dimaksud pada ayat (1) huruf b dilaksanakan melalui seleksi kaderisasi secara demokratis sesuai dengan AD dan ART dengan mempertimbangkan paling sedikit 30\% (tiga puluh per seratus) keterwakilan perempuan."

Affirmative Action dalam kepengurusn partai politik diharapkan mampu memberi ruang bagi perempuan untuk dapat masuk dalam jabatan politik, pada kenyataan perempuan masih memiliki hambatan yang lebih untuk dapat duduk pada jabatan politik dalam kepengurusan partai.

Stereotip yang diskriminatif terhadap perempuan yang membuat perempuan termarjinalisasi dalam politik. Marjinalisai perempuan dalam politik tidak terlepas dari budaya patriarki yang sudah lama merekat di Indonesia. Stereotif perempuan yang di

\footnotetext{
${ }^{7}$ Lihat Jumlah Perolehan Suara Sah Pileg 2014
} 
gambarkan harus mengerjakan pekerjaan domestik menjadikan perempuan di anggap sebagai warga negara nomor dua.

Maju sebagai kandidat kepala daerah membutuhkan pertimbangan yang matang, selama ini kepala daerah banyak diisi oleh laki-laki yang dinilai memiliki kapasitas dan kompetensi dalam memenangkan kontes pilkada.Untukmaju secara independen dinilai memiliki kemungkinan kecil untuk menang di bandingkan dengan di usung oleh partai politik.

Figur perempuan yang maju dalam pilkada cenderung memilih untuk mendapat dukungan partai politik.Partai politik dalam menseleksi kandidat yang di usung cenderung berpatokan pada elektabilitas dan modal ekonomi yang di miliki oleh calon kandidat.Jika melihat dari fakor tersebut, perempuan kalah bersaing dengan calon kandidat laki-laki yang memiliki elektabilitas yang lebih tinggi.Tidak banyak partai politik yang mau mengusung perempuan untuk maju dalam pilkada.Secara signifikan dapat kita lihat bahwa partai politik adalah kendaraan politik bagi baik kandidat perempuan maupun laki-laki untuk menang dalam pilkada.

\section{Partai Politik}

Partai politik sebagai pilar utama terhadap konsekuensi dari praktek demokrasi di Indonesia. Negara melihat bahwa masyarakat perlu diikut sertakan dalam proses politik, maka partai politik muncul sebagai jembatan penghubung antara pemerintah dan masyarakat, sehingga pada akhir abad ke-19 lahirlah partai politik yang pada masa selanjutnya berkembang menjadi penghubung antara rakyat di satu pihak dan pemerintah di pihak lainya. ${ }^{8}$ Fungsi partai politik pada masa lampau hanya berupa panitia-panitia yang mengatur pengumpulan suara menjelang pemilihan umum.

Seiring berkembangnya waktu para sarjanawan mendefenisikan partai politik sebagai sekelompok manusia yang terorganisir secara stabil dengan tujuan merebut atau mempertahankan kekuasaan terhadap pemerintahan bagi pimpinan partainya dan berdasarkan hal ini, memberikan manfaat bagi anggota partai yang bersifat ideal atau materiil. ${ }^{9}$ Pengertian lain yang menjelaskan tentang partai politik tertuang dalam UndangUndang No.2 Tahun 2011 tentang partai politik yang menyebutkan bahwa :

"Partai politik adalah organisasi yang bersifat nasional dan dibentuk oleh sekelompok warga negara Indonesia secara suka rela atas dasar kesamaan kehendak dan cita-cita untuk memperjuangkan dan membela kepentingan politik anggota, masyarakat, bangsa dan negara, serta memelihara keutuhan

\footnotetext{
${ }^{8}$ Op.Cit, Mariam Budiarjo, 2010, hal389

9 Muhadam Labolo \& Teguh Ilham, Partai Politikdan Sistem Pemilihan Umum di Indonesia, Jakarta: Rajawali Press, 2015, hal. 12
} 
negara kesatuan republik Indonesia berdasarkan pancasila dan Undang-Undang Dasar $1945^{\prime \prime 10}$

Dari uraian diatas tentang konsep partai politik dapat disimpulkan bahwa partai politik merupakan organisasi politik resmi yang dibentuk oleh orang-orang yang memiliki kepentingan dan tujuan yang sama untuk duduk di badan legislatif melalui mekanisme pemilihan umum.

\section{Rekrutmen Politik}

Tujuan dalam pembentukan partai politik adalah untuk merebut, mempertahankan dan menguasai kekuasaan dalam pemerintahan suatu Negara. Melalui Undang-undang Nomor 2 Tahun 2008 tentang partai politik pasal 10 ayat 1 sampai dengan 3 mengatur dengan jelas tujuan umum dan tujuan khusus dari partai politik sebagai berikut:

(1) Tujuan umum Partai Politik adalah:

a. Mewujudkan cita-cita nasional bangsa Indonesia sebagaimana dimaksud dalam Pembukaan Undang-Undang Dasar Negara Republik Indonesia Tahun 1945;

b. Menjaga dan memelihara keutuhan Negara Kesatuan Republik Indonesia;

c. Mengembangkan kehidupan demokrasi berdasarkan Pancasila dengan menjunjung tinggi kedaulatan rakyat dalam Negara Kesatuan Republik Indonesia; dan

d. Mewujudkan kesejahteraan bagi seluruh rakyat Indonesia.

(2) Tujuan khusus Partai Politik adalah:

a. Meningkatkan partisipasi politik anggota dan masyarakat dalam rangka penyelenggaraan kegiatan politik dan pemerintahan;

b. Memperjuangkan cita-cita Partai Politik dalam kehidupan bermasyarakat, berbangsa, dan bernegara; dan

c. Membangun etika dan budaya politik dalam kehidupan bermasyarakat, berbangsa, dan bernegara.

(3)Tujuan Partai Politik sebagaimana dimaksud pada ayat (1) dan ayat (2) diwujudkan secara konstitusional. ${ }^{11}$

Dalam sebuah Negara yang menganut sistem demokrasi, partai politik memerankan fungsi sentral dalam keberhasilan demokrasi Negara. Fungsi dari partai politik tersebut di jabarkan sebagai berikut: Pertama, fungsi komunikasi politik, partai politik menjadi

\footnotetext{
${ }^{10}$ UU RI, UU No. 2 tahun 2011, tentang Partai Politik

11 Undang-undang Republik Indonesia Nomor 8 Tahun 2008 tentang Partai Politik. 2008. Jakarta. http://www.dpr.go.id/dokjdih/document/uu/UU_2008_2.pdf. Diakses 12 Januari 2020
} 
jembatan antara masyarakat dan pemerintah.Partai politik merupakan komunikan sekaligus komunikator dalam menyampaikan regulasi, kebijakan ataupun keputusan pemerintah kepada masyarakat.Sebaliknya masyarakat menyampaikan pendapat dan aspirasi.Melalui komunikasi politik partai politik melakukan pengabungan aspirasi masyarakat agar lebih teratur dalam perumusan kepentingan. ${ }^{12}$

Kedua, fungsi sosialisasi politik merupakan proses yang dilalui seseorang dalam memperoleh sikap \& orientasi terhadap fenomena politik yang berlaku dalam masyarakat umumnya. ${ }^{13}$ Proses ini berlangsung dari masa kanak-kanak dan terus berlangsung sampai menyentuh sendi kehidupan organisasi masyarakat. Secara singkat partai politik mencoba menanamkan ideologinya kepada masyarakat baik melalui pendidikan politik ataupun melalui doktrin politik.Sarana pengatur konflik di perlukan terutama pada masyarakat heterogen.Partai politik memainkan peran sebagai jembatan penghubung antara pemerintah dan masyarakat, melalui konsolidasi dan artikulasi kepentingan. ${ }^{14}$ Fungsi terakhir yakni rekrutmen politik yakni merekrut orang-orang untuk diikutsertakan dalam kontes politik baik untuk menduduki posisi legislatif ataupun eksekutif.Mencari dan menjaring sumber daya manusia yang dapat di dukung untuk menjadi elite dalam partai.

Penelitian ini menggunakan dan menganalisis salah satu fungsi partai politik yakni rekrutmen politik.Fungsi rekrutmen politik merupakan fungsi eksklusif yang hanya dapat dilakukan oleh partai politik.Gabriel Almond menjelaskan proses rekrutmen politik merupakan kesempatan rakyat untuk menyeleksi kegiatan-kegiatan politik dan jabatan pemerintahan melalui penampilan dalam media komunikasi, menjadi anggota organisasi, mencalonkan diri untuk jabatan tertentu, pendidikan dan latihan. ${ }^{15} \mathrm{Czudnowski} \mathrm{menjelaskan}$ rekrutmen politik sebagai proses dimana individu/kelompok individu dilibatkan dalam peran-peran politik aktif. Melalui rekrutmen politik dapat menujukan dinamika yang terjadi dalam partai politik. ${ }^{16}$

Rekrutmen politik dapat menujukan kekuasaan dalam partai politik.Beberapa kasus partai politik di Indonesia dimana, partai politik yang memiliki 2 kubu dalam satu partai mencalonkan kandidat yang berbeda.Seperti yang terjadi di partai Golkar yang terbagi atas kubu Agung Laksono dan Kubu Aburizal Bakrie, sering kali keduanya mengirimkan 2 kandidat yang berbeda untuk maju dalam pilkada.Oleh sebab itu, Schattschneider mengatakan siapa yang menentukan rekrutmen politik maka dialah pemilik partai ${ }^{17}$.

\footnotetext{
${ }^{12}$ Op.cit Mariam Budiarjohlm. 405

${ }^{13}$ Ibid hlm. 407

${ }^{14}$ Ibid hlm. 409

${ }^{15}$ Op.Cit, Muhadam Labolo dan Teguh Ilham 2015, hal. 17.

${ }^{16}$ Sigit Pamungkas,Partai Politik: Teori dan Praktik di Indonesia, Institute for Democracy and Welfarism, Yogyakarta, 2011hal. 91

${ }^{17}$ Ibid., hal. 90
} 
Rekrutmen politik menggambarkan perjuangan kekuasaan internal partai, sehingga dapat dilihat bagaimana distribusi kekuasan dalam partai terbagi. Sirkulasi elite dalam partai dapat dilihat melalui rekrutmen politik, melihat bagaimana proses pengatian elite satu dengan elite lain. Pasca rekrutmen politik dilakukan, akan terlihat sosok wajah partai yang merepresentasikan wajah partai melalui kader partai. Ketika PDI-P merekrut Joko Widodo, wajah partai PDI-P digambarkan sebagai partai yang memperjuangkan suara rakyat dan memiliki kader yang mampu bekerja. Lebih lanjut rekrutmen politik dapat mendefinisikan tipe kepartaian apakah partai tersebut partai kartel, catch all, kader, massa atau business firm.

\section{Pola Rekrutmen Politik}

Partai politik merupakan satu-satunya institusi formal yang melakukan rekrutmen dalam pengisian jabatan-jabatan politik.Pola rekrutmen partai sendiri dinilai krusial karena merupakan tahap awal bagi partai politik untuk mendapatkan sumber daya manusia yang baik dan bermutu. ${ }^{18}$ Banyak teori rekrutmen politik yang dapat digunakan sebagai mata pisau bedah dalam menganalisis pola rekrutmen partai politik.

Dalam penelitian ini peneliti memilih konsep dan teori rekrutmen politik yang dikemukakan oleh Norris.Terdapat tiga tahap dalam rekrutmen politik, yaitu sertifikasi, penominasian, dan tahap pemilu.Perlakuan partai politik terhadap keseluruhan tahap-tahap rekrutmen politik sangat berhubungan dengan bagaimana partai politik mengorganisasikan diri.Tahap sertifikasi adalah tahap pendefinisian kriteria yang dapat masuk dalam kandidasi. ${ }^{19}$ Dalam tahapan ini penting untuk memahammi aturan dalam pemilihan dan aturan dalam AD/RT partai, serta norma-norma sosial informal.Tahapan selanjutnya adalah penominasian.Ada beberapa faktor yang berpengaruh penominasian yakni ketersedian calon yang memenuhi syarat dan permintaan dari penyeleksi ketika memutuskan siapa yang dinominasikan. Tahapan terakhir adalah pemilu yang menentukan siapa pemenang yang akan akhirnya.

Perlakuan partai politik terhadap keseluruhan tahap-tahap rekrutmen politik sangat berhubungan dengan bagaimana partai politik mengorganisasikan diri. Terdapat empat hal penting yang dapat menunjukan bagaimana pengorganisasian partai politik dalam rekrutmen politik yaitu: ${ }^{20}$

1. Siapa kandidat yang di dominasikan?

2. Siapa yang menyeleksi?

3. Dimana kandidat di seleksi?

\footnotetext{
${ }^{18}$ Ibid.,hlm. 18

${ }^{19} \mathrm{Ibid}, \mathrm{hlm} .90$

${ }^{20} \mathrm{Ibid}$, hlm.93.
} 


\section{Bagaimana kandidat di putuskan?}

Untuk melihat siapa kandidat yang dapat dinominasikan dalam rekrutmen politik dapat diklasifikasikan berdasarkan tingkat inklusifitas atau eklusifitas. Model Inklusif dijabarkan sebagai setiap pemilih dapat menjadi kandidat partai, tergantung bagaimana regulasi di negara tersebut. Dalam model Eklusifitas ada kondisi yang membatasi hak pemilih untuk dapat ikut serta dalam seleksi kandidat, ada tambahan regulasi dari partai politik selain yang sudah ditentukan oleh Negara.

Menelaah penyeleksi kandidat dapat di tentukan oleh lembaga yang terdiri dari satu orang atau lebih.Dapat di jabarkan melalui dua model yakni model inklusif yang mana pemilih yang memiliki hak memilih dalam pemilu.Ataupun model eklusif kandidasi ditentukan oleh pimpinan partai. Pimpinan partai sebagai agen pembuat keputusan dapat di klasifikasi dalam beberapa dimensi:

a. Dimensi penyebaran kekuasaan yakni pusat, regional atau lokal.

b. Dimensi formalisasi keputusan dibuat yakni Formal ketika ada standar prosedur baku dalam proses rekrutmen dan Informal ketika tidak ada standar prosedur khusus dalam proses rekrutmen.

Dari kedua dimensi tersebut terdapat beberapa tipe proses seleksi kandidat

1) Informal terpusat dengan mekanisme demokratik konstitusional, tapi pada realisasinya sebagai patronase kepemimpinan.

2) Informal regional adanya tawar-menawar antara faksi pemimpin untuk menempatkan kandidat favorit dalam posisi yang menguntungkan

3) Informal lokal, dimana proses rekrutmen dilakukan oleh penguasa lokal, kemungkinan proses rekrutmen terjadi tanpa adanya panduan yang jelas dengan kemungkinan berubah-ubah, rawan akan manipulasi oleh kelompok kecil.

4) Formal terpusat dan formal regional yakni pimpinan partai pusat dan regional memiliki otoritas konstitusional untuk memutuskan kandidat yang maju.

5) Formal lokal yakni aturan konstitusional dan panduan nasional dimapankan dalam proses rekrutmen sehingga memungkinkan pengunaan sistem ini transparan dan adil.

Dalam penyeleksian kandidat, terdapat dua metode yaitu, pertama, sentralistik dimana kandidat diseleksi secara eklusif oleh partai pada tingkat nasional, seperti representasi teritorial atau fungsional. Kedua, desentralisasi merupakan seleksi kandidat yang dilakukan secara eklusif oleh partai lokal atau kelompok intra partai. Ketiga, desentralisasi teritorial adalah seleksi di tingkat lokal yaitu nominasi kandidat dilakukan oleh pimpinan partai lokal. Keempat, desentralisasi fungsional yakni selesi dilakukan oleh 
korporasi yang memberikan jaminan representasi untuk kelompok dagang, perempuan, minoritas dsb.

Tahap selanjutnya adalah tahap nominasi kandidat, terdapat 2 model dengan klasifikasi sebagai berikut, model pemilihan dimana semua kandidat diseleksi melalui prosedur pemilihan tanpa seorangpun dapat mengubah daftar komposisi. Model penunjukan dimana kandidat murni ditunjuk untuk maju tanpa membutuhkan persetujuan oleh agensi partai.

\section{Pemilihan Kepala Daerah (Pilkada)}

Pemilihan kepala daerah atau yang lebih dikenal dengan pilkada adalah sarana kedaulatan rakyat yang diselengarakan lima tahun sekali untuk mengisi jabatan eksekutif di daerah pada tingkat Provinsi yakni gubernur dan wakil, tingkat kabupaten yakni bupati dan wakil, pada tingkat kota yakni walikota dan wakil.

Pemilihan kepala daerah secara langsung selanjutnya dituangkan dalam UndangUndang Nomor 32 Tahun 2004, Kepala Daerah adalah Kepala Pemerintah Daerah yang dipilih secara demokratis. Pemilihan secara demokratis terhadap kepala daerah tersebut dilakukan oleh rakyat secara langsung.Kepala daerah dan wakil kepala daerah dipilih secara langsung oleh rakyat yang persyaratan dan tata caranya ditetapkan dalam peraturan perundang-undangan. Dalam Peraturan KPU No. 12 Tahun 2015 tentang Pencalonan Pemilihan Gubernur dan Wakil Gubernur, Bupati dan Wakil Bupati, dan/atau Walikota dan Wakil Walikota pada pasal 38 dijelaskan sebagai berikut:

(1) Partai Politik atau Gabungan Partai Politik tingkat provinsi mendaftarkan Pasangan Calon Gubernur dan Wakil Gubernur kepada KPU Provinsi/KIP Aceh dan Partai Politik atau Gabungan Partai Politik tingkat kabupaten/kota mendaftarkan Pasangan Calon Bupati dan Wakil Bupati atau Walikota dan Wakil Walikota kepadaKPU/KIP Kabupaten/Kota selama masa pendaftaran sebagaimana dimaksud dalam Pasal 37 ayat(3).

(2) Dalam mendaftarkan Pasangan Calon sebagaimana dimaksud pada ayat (1), Partai Politik atau Gabungan Partai Politik wajib memenuhi persyaratan: a. ketentuan Pasal 5 ayat (2) dan ayat (3); b. menyertakan Keputusan Pimpinan Partai Politik tingkat pusat tentang persetujuan Pasangan Calon dan dokumen syarat calon; dan c. menyertakan Keputusan Pimpinan Partai Politik tingkat pusat tentang kepengurusan Partai Politik tingkat provinsi dan/atau kepengurusan Partai Politik tingkat kabupaten/kota. ${ }^{21}$

\footnotetext{
${ }^{21}$ Peraturan KPU NO. 12 Tahun 2015, tentang Pencalonan Pemilihan Gubernur dan Wakil Gubernur, Bupati dan Wakil Bupati, dan/atau Walikota dan Wakil Walikota.
} 
Pasangan calon Kepala Daerah dan Wakil Kepala Daerah dapat dicalonkan baik oleh partai politik atau gabungan partai politik peserta pemilu yang mempunyai minimal atau lebih kursi $20 \%$ dalam DPRD dan atau memperoleh dukungan suara minimal atau lebih dari $20 \%$ dalam pemilu legislatif. Peran partai politik tampak dalam Undang-Undang No 8 Tahun 2015 yang merupakan revisi Undang-Undang No 1 Tahun 2014 tentang Pilkada Gubernur, Bupati dan Walikota. Dalam undang-undang tersebut menyebutkan bahwa:

"Partai politik maupun gabungan partai politik dapat mengajukan bakal calon kepala daerah bila memiliki 20 persen kursi di DPRD maupun 25 persen suara sah perolehan dalam pemilu legialastif DPRD 2014."

Artinya bila partai politik tersebut memiliki kursi lebih dari 20 persen di DPRD ataupun perolehan suara lebih dari 25 persen, dapat mengajukan kandidat sendiri. Jika tidak, maka harus bergabung dengan partai lainnya (koalisi) agar memenuhi jumlah kursi 20 persen atau 25 persen suara untuk dapat mengajukan bakal calon kepala daerah. Untuk mengajukan kandidat bakal calon tersebut, tentunya partai politik harus memiliki kepengurusan yang sah. ${ }^{22}$

Untuk maju dalam pilkada Negara mengatur 2 jalur yang dapat digunakan oleh warga negara untuk dapat maju dalam pemilihan. Pertama, jalur independen, melalui jalur ini individu harus mengumpulkan massa melalui pengumpulan kolektif foto copy KTP. Kedua melalui jalur partai, dimana partai politik yang memiliki anggota DPRD yang cukup dan memperoleh suara yang cukup dalam pileg sebelumnya berhak mengusung pasangan kandidat.

\section{METODE PENELITIAN}

Penelitian ini mengunakan metode penelitian kualitatif. Penelitian Kualitatif merupakan fokus perhatiandengan beragam metode yang mencakup pendekatan interpretif dan naturalistik terhadap subjek kajianya. ${ }^{23}$ Bogdan dan Taylor menjelaskan bahwa penelitian kualitatif adalah prosedur penelitian yang menghasilkan data deskriptif berupa kata-kata tertulis atau lisan dari orang-orang dan perilaku yang dapat diamati. Penelitian kualitatif dipilih agar memperoleh gambaran seutuhnya mengenai rekrutmen politik yang dilakukan oleh PAN dan PKB menurut pandangan manusia yang menjadi obyek kajian.

Desain penelitian mengunakan metode studi kasus yang mana merupakan studi mendalam mengenai unit sosial tertentu dan bahwa hasil penelitian tersebut memberikan

\footnotetext{
${ }^{22}$ Angga Natalia. Jurnal.PERAN PARTAI POLITIK DALAM MENSUKSESKAN PILKADA SERENTAK DI INDONESIA TAHUN 2015. Vol. 11 No. 1. 2015 Di akses pada 22 Februari 2018

${ }^{23}$ Norman K. Denzin dan Yvonna S. Lincoln, Handbook of Qualitative Research, Yogyakarta: Pustaka Pelajar, 2009, hal. 2
} 
gambaran luas, serta mendalam mengenai unit sosial tertentu. ${ }^{24}$ Penelitian ini berlokasi di Kabupaten Muaro Jambi, Provinsi Jambi. Unit analisi yang digunakan dalam penelitian ini adalah institusi yakni, partai politik. Teknik pengumpulan data menggunakan wawancara dan dokumentasi, sedangkan informan dipilih dengan cara purposive sampling. teknik analisis data menggunakan data emik dan etik. Sedangkan untuk keabsahan data, peneliti menggunakan triangulasi antar sumber data.

\section{HASIL dan PEMBAHASAN}

\section{Pelaksanaan Rekrutmen Calon Kepala Daerah Kabupaten Muaro Jambi Oleh Partai PKB dan Partai PAN}

Pemilihan kepala daerah Kabupaten Muaro Jambi pada tahun 2017 dimenangkan oleh pasangan Masnah Busro-Bambang Bayu Suseno.Partai politik merupakan kendaraan yang membawa kandidat untuk memenangkan pemilihan. Dalam proses pemilihan kepala daerah andil partai politik dalam menentukan kandidat yang diusung sangat signifikan.

\section{Proses Seleksi Kandidat di PKB Muaro Jambi}

Rekrutmen politik adalah sebuah proses dimana individu atau kelompok-kelompok individu dilibatkan dalam peran-peran politik aktif. ${ }^{25}$ Bakal calon kepala daerah dapat maju dalam pilkada dengan di usung oleh partai politik ataupun maju melalui jalur individu. ${ }^{26}$

Terdapat tiga tahap dalam rekrutmen politik, yaitu sertifikasi, penominasian, dan tahap pemilu.Perlakuan partai politik terhadap keseluruhan tahap-tahap rekrutmen politik sangat berhubungan dengan bagaimana partai politik mengorganisasikan diri.Tahap sertifikasi adalah tahap pendefinisian kriteria yang dapat masuk dalam kandidasi.Dalam tahapan ini penting untuk memahammi aturan dalam pemilihan dan aturan dalam AD/RT partai, serta norma-norma sosial informal.Tahapan selanjutnya adalah penominasian.Ada beberapa faktor yang berpengaruh penominasian yakni ketersedian calon yang memenuhi syarat dan permintaan dari penyeleksi ketika memutuskan siapa yang dinominasikan. Tahapan terakhir adalah pemilu yang menentukan siapa pemenang yang akan duduk di kursi eksekutif.

Berdasarkan asumsi peneliti dalam pengumpulan data yang dilakukan peneliti berharap data tersebut dapat menjadi jawaban dari pertanyaan dalam persoalan dalam penelitian ini, serta bisa menjadi bahan dalam menganalisis dan memenuhi kebutuhan dari tujuan penelitian ini yaitu untuk mengetahui dan menganalis tentang proses rekrutmen partai PAN dan PKB dalam merekrut Masnah Busro dalam pilkada Muaro Jambi 2017.

\footnotetext{
${ }^{24}$ Imam Gunawan, Metode Penelitian Kualitatif Teori dan Praktik, Jakarta: Bumi Aksara, 2013, hal.112

25 Sigit Pamungkas,op.cit, hlm. 91

${ }^{26}$ Ibid, hlm. 91
} 
Dengan adanya proses rekrutmen politik, partai politik mampu mengantarkan warga negaranya untuk duduk di kursi pemerintahan baik eksekutif ataupun legislatif. Partai politik merupakan konsekuensi demokrasi, untuk itu partai politik memiliki tugas untuk mengartikulasi kehendak publik, mengadakan pendidikan politik, mengembangkan dan menawarkan alternatif kebijakan dan menyediakan pilihan politik kepada masyarakat dalam pemilu.

Partai politik dalam menjalankan fungsi rekrutmen melalui banyak tahapan. Partai PKB dan PAN sebagai objek penelitian memulai tahapan rekrutmen dengan proses seleksi administratif. Partai politik sebagai kendaraan yang dapat mengantarkan bakal calon untuk duduk di kursi politik mempunyai andil besar dalam proses pilkada.

Dalam melakukan proses seleksi bakal calon bupati, partai PKB membentuk panitia kecil yang tugasnya melakukan seleksi administratif bakal calon yang mendaftar. Penyeleksian kandidat bakal calon PKB mengunakan model eksklusif yaitu elit partai menentukan seleksi kandidat. Model rekrutmen kandidat berdasarkan dimensi kekuasan tersentralisasi di pusat. Kekuasaan pusat terhadap keputusan seleksi kandidat mutlak, panitia desk-pilkada maupun pengurus daerah tidak dapat mempengaruhi hasil yang sudah di putuskan oleh pengurus pusat. Menelaah formalitas keputusan dibuat, keputusan dibuat melalui proses formal yang berarti terdapat standarisasi prosedur yang mengikat dalam proses rekrutmen. Model formal-terpusat yang digunakan menjadikan eksekutif partai pusat yang menjadi penentu hasil dari seleksi kandidat yang akan diusung PKB.

Dalam menjalankan proses rekrutmen perlu di identifikasi siapa saja bakal calon yang dapat diusung oleh partai. PKB memakai model pengelolaan inklusif. Model inklusif yakni setiap pemilih dapat menjadi kandidat. Terbukti dari Sembilan orang pendaftar yang berasal dari latar belakang berbeda, dikandidatkan untuk ikut dalam proses seleksi bakal calon. Dari sembilan peserta yang terdaftar, PKB menyerahkan sebanyak enam orang yang lulus untuk mengikuti proses fit and proper test di Jakarta. Keenam orang tersebut yakni: Wiranta, Agustian Mahir, Masnah Busro, Kemas Fuat dan Ahmad Haikal yang merupakan anggta partai sedangkan lima peserta lainya di luar anggota partai.

Secara teoritis, partai politik yang mengusung calon non-kader sebagai kandidat kepala daerah menunjukkan macetnya proses kaderisasi terutama di tingkat lokal. Ada beberapa sebab macetlya kaderisasi ini.Pertama, kurangnya kuantitas dan kualitas kader yang masuk ke dalam partai.Kedua, kader-kader yang masuk ke partai tidak mempunyai kapabilitas sebagai politisi.Mereka masuk ke partai cenderung sebagai simpatisan, tanpa latar belakang yang memadai untuk berkiprah dalam politik maupun pemeintahan.Ketiga, mekanisme penjenjangan kaderisasi yang berlangsung dalam partai cenderung tidak transparan. Penempatan individu pada jabatan strategis dalam partai bukan berdasar kapabilitas dan keahlian, namun pada kedekatan dengan elit maupun kemampuan untuk 
menyumbang dana. Hal ini berujung dengan kader-kader yang mempunyai kemampuan namun minim dana, tidak bisa meniti jenjang karir politik secara mulus.

Beberapa poin tersebut membuat partai-partai pemenang pemilu mengalami krisis ketersediaankader handal.Ketika dihadapkan pada momentum pilkada, mau tidak mau partai harus bersikap pragmatis dengan mengambil kandidat yang berasal dari luar partai. Dengan alasannya aktor tersebut mempunyai elektabilitas tinggi, ataupun kemampuan dana yang memadai. ${ }^{27}$ Ahmad Haikal merupakan kader partai PKB yang mendaftar seleksi kandidat di $\mathrm{PKB}$, namun dalam tahap penominasian di tingkat pusat dinyatakan tidak dapat melanjutkan pada tahapan berikutnya. Alasan PKB tidak meluluskan Ahmad Haikal yang merupakan kader partai sendiri dikarenakan adanya pertimbangan internal dalam PKB. PKB tidak dapat mengusung sendiri kandidatnya untuk maju dalam Pilkada Muaro Jambi, PKB harus menggandeng partai lain untuk sama-sama mengusung. Atas pertimbangan ini, Ahmad Haikal tidak diusung oleh PKB.

Untuk dapat melihat dimana kandidat di seleksi dapat dibedakan mengunakan dua metode yakni sentralisasi dan desentralisasi. Dalam proses kandidasi PKB mengunakan metode desentralisasi. Hasil keputusan pusat tidak dapat diintervensi oleh pengurus daerah. Keputusan pusat mutlak dan kandidat yang dipilihlah yang akan di usung untuk maju menjadi calon bupati nantinya.

Struktur organisasi partai politik yang mengunakan system sentralisasi dari tingkat pusat sampai dengan tingkat desa atau kelurahan memberikan konsekuensi yang cukup berpengaruh dalam proses rekrutmen politik yang berlangsung di dalam partai. Kepengurusan partai politik dengan sistem sentralisai menjadikan kepengurusan partai tingkat terbawah harus tunduk dan patuh sepenuhnya dengan kepengurusan partai di tingkat yang lebih tinggi. Konsekuensi dari system ini adalah jika ada keputusan yang berbeda antara pengurus pada tingkat atas dan pada tingkat dibawah, dapat dikenakan sangsi ataupun pemecatan dari struktur pengurus partai.

Proses seleksi kandidat calon bupati yang dilakukan oleh partai politik memang perkara yang pelik. PKB yang tidak bisa mengusungkan calon tanpa melakukan koalisi, memilih untuk tidak terlalu terburu-buru dalam menentukan kandidat yang akhirnya diusung. Sofyan Ali sebagai Ketua Partai PKB Provinsi Jambi mengakui adanya bisikan dari organisasi masyarakat yang dekat dengan PKB yakni Nahdathul Ulama yang cenderung merekomendasikan calon kandidat Amin. Realitas yang terjadi, walaupun NU sudah memberikan rekomendasi untuk mengusung kandidat Amin, Pengurus Pusat PKB memiliki pendapat yang berbeda. Hitung-hitung politik yang sudah dilakukan memutuskan

${ }^{27}$ Helmi Mahadi, Pragmatisme Politik: Studi Kasus Proses Rekrutmen Politik PDI-P pada Pilkada Kabupaten Sleman, Jurnal Studi Pemerintahan, Volume 2, 2011, hal. 7 
pengurus pusat untuk mengusung kandidat Masnah Busro-Bambang Bayu Suseno untuk diususng pada Pilkada Muaro Jambi tahun 2017.

Ketika waktu pendaftaran sudah dekat dan keputusan pengurus pusat condong antara ikut mengusung pasangan Ivan-Dodi atau menjadi partai pengusung Masnah yang belum memiliki partai pendukung sama sekali, PKB memutuskan untuk berkoalisi dengan PAN dan mengusung pasangan Masnah Busro-Bambang Bayu Suseno untuk maju dalam pemilihan bupati Muaro Jambi.

Karir politik Masnah Busro cukup panjang sebelum memenangkan Pilkada Muaro Jambi tahun 2017. Masnah Busro pada tahun 2011 pernah mengikuti pilkada Kabupaten Muaro Jambi namun kalah dalam pemilihan. Pilkada Muaro Jambi tahun 2011, Masnah Busro maju berpasangan dengan Arifin. Bakal calon Masnah Busro-Arifin maju dalam pilkada Muaro Jambi tahun 2011 melalui jalur independent, partai tempat keduamya bernaung tidak memberikan dukungan keduanya untuk maju dalam pilkada.

Dalam pilkada 2017 Masnah Busro memutuskan untuk kembali bertarung dalam memperebutkan kursi kepala daerah. untuk maju Masnah Busro membutuhkan dukungan partai politik. Sebelum diumukan di usung oleh PKB, Masnah Busro adalah Anggota DPRD Provinsi Jambi dari partai Golkar.

Tidak ingin mengulang kekalahan yang sebelumnya, Masnah Busro mencoba mencari partai politik yang mau mengusung dirinya untuk maju dalam pemilihan. Melihat kondisi partai Golkar yang sudah yakin untuk mengusung kandidat Ivan Wiranta, hal ini membuat Masnah Busro mencari partai lain yang mau mengusung dirinya dalam pilkada di Kabupaten Muaro Jambi. Seluruh proses seleksi kandidat telah Masnah Busro ikuti hingga akhirnya PKB yakin untuk mengusung Masnah Busro-Bambang Bayu Suseno.

\section{Proses Seleksi Kandidat oleh PAN Muaro Jambi}

Seleksi kandidat pada PAN diawali dengan dilakukanya survei keterpilihan kandidat di masyarakat. Survei yang dilakuan ini diharapkan mampu melihat sosok kepala daerah yang diinginkan oleh masyarakat Kabupaten Muaro Jambi. Hasil dari survey yang dilakukan dijadikan landasan partai PAN dalam melakukan seleksi kandidat untuk diusung dalam Pilkada Muaro Jambi tahun 2017.

Dari hasil survei yang dilakukan PAN melihat sosok Bambang Bayu Suseno mampu mengemban tugas sebagai kepala daerah di Kabupaten Muaro Jambi. Potensi dalam memenangkan pilkada terlihat dari hasil survei, namun memang membutuhkan usaha yang lebih untuk dapat memenangkan pilkada. Dari sisi elektabilitas, Bambang Bayu Suseno sudah terbukti dilihat dari keberhasilan Bambang Bayu Suseno untuk duduk di kursi DPRD Provinsi Jambi dengan perolehan suara 10.399 suara. 
Lebih jauh hasil survei yang didapat digunakan oleh PAN untuk menganalisis kemungkinan menang dan kalah, memetakan kekuatan politik lawan, melihat kombinasi bupati dan wakil bupati yang cocok, dan untuk melihat kecenderungan pilihan masyarakat dalam memilih kepala daerah.

Proses seleksi kandidat dalam partai PAN memang diawali dengan dilakukanya survei elektabilitas dan polularitas. Agar proses seleksi kandidat berlangsung efektif dan efisien pengurus DPD PAN Kabupaten Muaro Jambi membentuk panitia kecil yang akan menangani proses seleksi kandidat. Pembentukan panitia kecil dalam menagani proses seleksi kandidat secara administratif memang menjadi standar awal bagi setiap partai yang akan mengusung kandidat untuk maju dalam proses pilkada. Pembentukan panitia ini dilakukan pada partai yang mengunakan model inklusif ataupun eksklusif seperti yang digunkan oleh PAN.

Untuk melihat model seleksi kandidat partai PAN dalam mencari kandidat yang di usung, PAN lebih mengunakan model eksklusif dimana tidak semua orang dapat diusung oleh PAN. Dari awal mencari kandidat yang akan maju untuk pemilihan bupati, PAN memang mencari kader dari dalam partai untuk diusung. Alasan dibalik keharusan mengusung kader untuk maju dalam pilkada adalah demi berkembangnya partai kedepan. Partai PAN secara umum di Provinsi Jambi merupakan partai yang cukup berpengaruh. Untuk itu, PAN cenderung mengusung kader di dalam partai untuk maju dalam pilkada. Proses ini menujukan bahwa sistem kaderisasi dalam tubuh partai PAN berjalan dengan baik. Ketika momentum pilkada datang, PAN tidak kerusuhan mencari figure di luar partai untuk di usung. Kader dalam partai PAN siap untuk bertarung dalam pilkada. Bersinerginya antara PAN dan kadernya untuk maju dalam pilkada menujukan kesipan PAN dalam pertarungan kursi kepala daerah di Kabupaten Muaro Jambi. Ketika mengerucut membahas syarat khusus untuk diusung sebagai kandidat dari PAN adalah memenuhi syarat yang diberikan oleh KPU, mampu memenangkan pemilihan dan merupakan anggota PAN aktif.

PAN memang berkeras dalam hal mencari figure yang mampu membawa partai untuk berkembang. Proses berkembangnya partai ini penting demi keberlangsungan kehidupan partai dalam kehidupan berpolitik. Perkembangan seperti ini terlihat baik di mata masyarakat yang menilai kader PAN mupuni dalam menjalankan roda pemerintahan. Di mata masyarakat PAN mampu menggambil kepercayaan masyarakat dengan melalui kader yang berkualitas.

PAN menggunakan model penyeleksian kandidat secara eksklusif dimana kandidasi ditentukan oleh pimpinan partai. Dalam melihat formalitas keputusan yang telah dibuat, PAN dalam hal seleksi kandidat mengunakan model formal terpusat. Model ini menjadikan pusat memiliki otoritas konstitusional dalam menentukan seleksi kandidat. 
Menilai dimana kandidat diseleksi, untuk melihat derajat desentralisasi PAN mengunakan model sentralistik. Seleksi kandidat dilakukan pada tingkat nasional. Dalam hal ini, DPP PAN memiliki kuasa secara otoritas dalam menentukan kandidat yang akan di usung.

Model seleksi sentralistik memang banyak digunakan dalam menentukan kandidat yang maju dalam pemilihan. Fenomena seperti ini terus terjadi karena kepengurusan partai di pusat tetap ingin memegang kendali dari pengurus di daerah. Kepengurusan pusat tetap ingin menjadi pemegang otoritas dari hasil final proses seleksi kandidat. Baik PAN dan PKB mengunakan model sentralistik dengan alasan yang sama. Dalam tubuh PAN menelaah bagaimana kandidat dinominasikan model yang digunakan adalah pemilihan. Model pemilihan yakni prosedur pemilihan yang murni, tanpa seorang pun dapat mengubah daftar komposisi.

Seleksi kandidat bupati diajukan oleh partai politik sesuai peraturan yang berlaku. Baik PKB dan PAN tidak dapat mengajukan calon tanpa berkoalisi dengan partai lain. Perolehan kursi di DPRD dari dua partai tersebut kurang untuk dapat menunjukan sendiri anggota yang akan diusung. Diperlukan sebuah seleksi kandidat untuk dapat menemukan figur yang tepat untuk di usung kedua partai.

Komposisi bupati dan wakil bupati terjadi dalam proses seleksi di pusat. Baik DPP PKB dan DPP PAN menjadi ujung tombak dalam pemutusan seleksi kandidat. Sekaligus menentukan komposisi bupati dan wakil bupati, setelah komposisi ditentukan DPP dari kedua partai menerbitkan SK pengusungan dan langsung didaftarkan ke KPU di Kabupaten Muaro Jambi.

Dalam proses seleksi kandidat, banyak faktor yang dipertimbangkan dalam menentukan kemenangan pilkada. Elektabilitas kandidat, ketokohan kandidat, serta cost politic yang akan dikeluarkan. Semua faktor tersebut bukanlah hal yang mudah untuk dipenuhi oleh seorang kandidat. Untuk memenangkan sebuah pilkada diperlukan dana yang tidak sedikit. Kandidat yang diusung mampu memenuhi biaya operasional selama proses kampanye ataupun sosialisasi di masyarakat.

Siavelis dan Morgenstern menyatakan bahwa rekrutmen politik sangat ditentukan oleh dua variable yakni, variabel legal dan variabel partai politik. ${ }^{28}$ Dalam rekrutmen eksekutif variabel legal yang mempengaruhi mencangkup sistem pemilu, waktu pelaksanaan pemilu, hambatan untuk kandidat independen, peluang petahana untuk dipilih kembali, dan bentuk Negara. Sedangkan dalam variabel partai politik mencangkup derajat

\footnotetext{
${ }^{28}$ Pamungkas, op. cit hlm. 104
} 
inklusifitas rekrutmen, pengorganisaian partai, derajat indentifikasi partai, pemilih, dan relasi partai dengan uang. ${ }^{29}$

PAN sebagai partai yang juga harus mencari koalisi untuk dapat mencalonkan kandidat memperhitungkan peta kekuatan politik di Kabupaten Muaro Jambi. Survei kandidat calon bupati dilakukan untuk melihat elektabilitas dan popularitas yang ada di masyarakat. Lebih lanjut, PAN menimbang-nimbang kombinasi yang mampu memenangkan pilkada ini. Bambang Bayu Suseno sebagai kandidat yang dipilih PAN untuk maju dalam pilkada Muaro Jambi dengan pertimbangan popularitas dan elektabilitas yang sudah terbukti dengan berhasil duduk di kursi DPRD Provinsi.

Adanya kepercayaan terhadap hasil elektabilitas dan popularitas yang dimiliki oleh Bambang Bayu Suseno, PAN, sebagai partai yang mengusung berusaha mencari pasangan calon dan partai yang dapat berkoalisi. Dengan pertimbangan tersebut PKB dan PAN melakukan koalisi dalam mengusung kandidat Masnah Busro-Bambang Bayu Suseno.

Keputusan ini dilakukan tidak jauh dari kesadaran kedua belah partai akancost politic yang ada untuk jalan menuju kemenangan. Pasangan kandidat ini, dipercaya memiliki modal ekonomi yang cukup untuk operasional selama kampanye dan sosialisasi yang berlangsung. Elektabilitas dan popularitas dari pasangan tersebut kuat di dalam masyarakat, keduanya memenangkan pileg dan duduk di kursi legislative pada 2014. Lebih jauh, pasangan ini didukung oleh gubernur terpilih Zumi Zola Zulkifli yang saat itu masih menjabat sebagai Ketua PAN Provinsi Jambi. Dengan adanyanya modal ekonomi dan power di sisi Masnah Busro-Bambang Bayu Suseno PAN dan PKB optimis kemenangan pilkada pada kandidat yang mereka ususng.

Fungsi rekrutmen politik yang dilaksankan oleh partai memainkan andil yang besar atas kemenangan pasangan Masnah Busro-Bambang Bayu Suseno. Proses yang dilakukan oleh PKB dan PAN dalam mencari kandidat yang diusung untuk maju dalam pemilihan membuktikan pentingnya peranan partai politik sebagai kendaraan bagi kandidat untuk maju dalam pilkada. Partai politik memang seharusnya menjadi kendaraan yang dapat menghantarkan kandidatnya untuk dapat duduk di kursi pimpinan. PAN dan PKB tidak menjadikan faktor gender sebagai penghalang untuk siapa saja untuk dapat diusung oleh kedua partai.

Langkah yang ditempuh oleh partai-partai politik ini bukan tanpa alasan.Hal ini karena partai politik yang menang pemilu tidak otornatis berjaya dalam pilkada. Menurut catatan LSI (2005), sebagian besar (72,3\%) Pilkada dimenangkan oleh partai atau koalisi partai yang bukan pemenang pemilu legislatif.Ada beberapa hal yang mungkin bisa menjelaskan fenomena di atas.Pertama,berbeda dengan pemilu legislatif yang berbasis

\section{${ }^{29}$ Ibid.}


partai politik. Pilkada di sisi lain berbasis individu kandidat. Dengan demikian, ketokohan seorang figur kandidat akansangat menentukan tingkat keterpilihannya. Karena itu, sosok incumbent menjadi rebutan partai-partai pemenang untuk mencalonkannya kembali. Selain karena sosok incumbent sudah sangat populer, kedudukamya sebagai pejabat diduga bisa dimanfaatkan untuk memobilisasi danamaupun dukungan dari masyarakat. Kedua, faktor popularitas saja belum cukup untuk memenangi pilkada.Faktor modal finansial juga sangat menentukan dalam pilkada. Hal ini berarti, bahwa partai yang besar ataupun kandidat yang terkenal harus didukung pula oleh danayang memadai. Para kandidat mernbutuhkan biaya yang cukup besar untuk bisa meraih simpati massa sekaligus memobilisasi para pemilih tersebut. ${ }^{30}$

\section{KESIMPULAN}

Proses seleksi oleh partai politik diawali dengan menjabarkan tahap demi tahap penentuan seleksi kandidat. Upaya yang dilakukan PKB dalam melakukan seleksi kandidat diawali dengan seleksi administratif yang dilakukan pada tingkat kabupaten. Setelah melewati proses seleksi administratif, kandidat yang terjaring mengikuti tahapan selanjutnya yang dilakukan oleh tingkat pusat. Pada tingkat pusat ini terjalin komunikasi politik untuk mempertimbangkan kandidat mana yang akan diusung. Pada tingkat pusat inilah keputusan final penetuan kandidat yang di usung dilakukan. Rekrutmen kandidat yang dilakukan PKB mengunakan model Inklusif dalam menentukan siapa kandidat yang dapat diususng. Dalam penentuan siapa yang melakukan penyeleksian terhadap kandiat PKB mengunakan model Formal-Terpusat yang bersifat sentralistik.Untuk menentukan dimana kandidat di seleksi PKB mengunakanmodel eksklusif. Dan untuk melihat bagaimana kandidat diputuskan PKB mengunakan model Pemilihan. Selain itu, di tingkat pusat terjalin komunikasi pula dengan partai lain untuk mencari kombinasi calon bupati dan calon wakil bupati.

Tahapan yang hampir sama terjadi dalam proses rekrutmen politik yang dilakukan oleh partai PAN. PAN menggawali proses pencarian kandidat dengan melakukan survey elektabilitas dan popularitas di masyarakat. Mencari gambaran figur pimpinan seperti apa yang dicari oleh masyarakat. Setelah proses survey selesai, PAN memilih kader di dalam partai sendiri untuk diusungkan. Proses seleksi kandidat tidak serta merta selesai pada titik ini, DPP yang menentukan hasil akhir dari proses seleksi kandidat. Dalam pencarian kandidat yang akan diusung untuk maju dalam Pilkada Muaro Jambi tahun 2017 PAN mengunakan model ekslusif dalam menentukan kandidat yang dinominasikan. Dalam penentuan siapa yang melakukan penyeleksian PAN mengunakan model Formal Terpusat. Untuk menentukan dimana kandidat dinominasikan PAN mengunakan model Ekslusif

${ }^{30}$ Helmi Mahadi, Pragmatisme Politik: Studi Kasus Proses Rekrutmen Politik PDI-P pada Pilkada Kabupaten Sleman, Jurnal Studi Pemerintahan, Volume 2, 2011, hal. 3 
dengan tipe sentralistik. Untuk melihat bagaimana kandidat diputuskan PAN mengunakan model Penunjukan. Pada tingkat pusat terjadi proses koalisi untuk menentukan komposisi bupati-wakil bupati.

PKB dan PAN Kabupaten Muaro Jambi telah berhasil melaksanakan fungsi rekrutmen politik dengan mengusung Masnah Busro dan Bambang Bayu Suseno.Lebih jauh keberhasilan PKB dan PAN memberikan kemenangan atas berhasilnya pasangan ini duduk di kursi kepala daerah untuk periode kepemimpinan 2017-2022.Koalisi kedua partai ini bersinegi untuk memenangkan pasangan calon agar dapat duduk di kursi kepala daerah.

\section{DAFTAR PUSTAKA}

Angga Natalia. (2015). Peran Partai Politik Dalam Mensukeskan Pilkada Serentak Di Indonesia. Vol. 11(1)

Helmi Mahadi. (2011). Pragmatisme Politik: Studi Kasus Proses Rekrutmen Politik PDI-P pada Pilkada Kabupaten Sleman. Jurnal Studi Pemerintahan.Volume 2

Gunawan, Imam. (2013). Metode Penelitian Kualitatif Teori dan Praktik, Jakarta: Bumi Aksara

Maharddhika. (2017). Perempuan Calon Kepala Daerah di Pilkada 2017. Jakarta: Perludem

Labolo, Muhadam. Ilham, Teguh. (2015). Partai Politikdan Sistem Pemilihan Umum di Indonesia, Jakarta: Rajawali Press

Norman K. Denzin dan Yvonna S. Lincoln, (2009). Handbook of Qualitative Research, Yogyakarta: Pustaka Pelajar

Peraturan KPU NO. 12 Tahun 2015, tentang Pencalonan Pemilihan Gubernur dan Wakil Gubernur, Bupati dan Wakil Bupati, dan/atau Walikota dan Wakil Walikota

Sigit Pamungkas, (2011). Partai Politik: Teori dan Praktik di Indonesia. Institute for Democracy and Welfarism, Yogyakarta

Sihombing, Irvin S.T, "Reformasi Demokrasi Internal Partai Politik: Sebuah Upaya Mencapai Negara Demokratis yang Hakiki”. Yayasan Perludem: Jakarta Selatan. "Tanpa Tahun"

Undang-undang No 2 Tahun 2011 tentang Partai Politik

Undang-undang Republik Indonesia Nomor 8 Tahun 2008 tentang Partai Politik. 2008. Jakarta. http://www.dpr.go.id/dokjdih/document/uu/UU_2008_2.pdf. Diakses 12 Januari 2020 